\title{
STRENGTHENING THE ROLE OF GOVERNMENT IN RESOLVING FRAUD AND DISPUTES OF THE FLAT MANAGEMENT
}

\author{
Situmorang Palmer*, Ahmad Rusniah, Noor Fauziah Bt. Mhd, Nursadi Harsanto \\ College of Law, Government and International Studies (COLGIS), \\ Universiti Utara Malaysia, Malaysia \& Faculty of Law, Universitas Indonesia, Indonesia \\ *E-mail: palmer@palmersitumorang.com
}

\begin{abstract}
The public concern with the housing issues and conditions including flat management becomes current phenomenon in developing countries such as Indonesia. However, less attention has been paid by researchers to discuss the role of government in the flat management. The fact is that fraud and disputes often occur as a result of the management of flats such as management fees and monthly billing invoice becoming the main issue at the court. Through case law approach method with four different cases, this paper therefore captures several issues related to the management of flats. For instance, this paper discusses a case where flat management companies tend to increase maintenance fees without having a consent or agreement, both from owners and tenants. Disputes are also related to transparency of collected management fees by flat management companies, causing dissatisfaction from the owners and tenants. Hence, this paper suggests that there is the need of government's role in the flat management issues. This suggestion is relevant to the idea of exercising government's power through monitoring flat management companies in order to comply with flat legislation. This paper argues that the use of government's authority could be practised through monitoring system and setting up administrative procedure on the management of flats.
\end{abstract}

\section{KEY WORDS}

Flats management, fraud, disputes, government, authority.

Human settlement and housing are still essential issues in today's life (see UNHABITAT, 2018). However, there are several challenges on housing arrangement such as the need of the provision of land (Aalbers and Gibb, 2014). It is the fact that land development for various purposes is increasing. Despite of the increase of residential development, the current availability of land is limited, both in terms of quality and quantity. As a result, several governments consider the importance of developing shared houses or residences in a multi-storey building, where units of flat can be owned separately (Hutagalung, 2007). This initiative provides an alternative in tackling problem of a high demand on housing and settlement (Public Communication Center, 2018), especially in urban areas where people population continues to increase. Other benefits of developing flats in a multi-storey building are: developing flats can reduce the massive use of land, developing flats are able to create more open spaces through the concept of shared facilities and public space, and developing flats can be a way to rejuvenate cities from slum areas (Hutagalung, 2005).

Technologically, the multilevel building system, in the sense of the function of building space used separately by different owners has been recognized and implemented in several big cities in Indonesia. However, the ownership system of the building is a sole proprietorship system, meaning the owner of land is also the owner of the building (Sutedi, 2010). Therefore, tenants of flats under this kind of ownership system are only bound in the form of

\footnotetext{
${ }^{1}$ The Head of the Agency's Research and Development (Balitbang) Department of public works (PU) Hendrianto Notosoegondo revealed, the needs a home that has not served the current backlog reached 5.8 million units. Although the national population growth tends to be decreased from 1.98 percent per year on 1980-1990 be 1.4 per cent per year on 1990-2000, but the growth of the urban population in 1990-2000 are still quite high which is 3.5 percent per year.
} 
a lease relationship without having material rights to the object of the agreement. Consequently, there is a limited use of the property by tenants.

Indonesia has a legal instrument in the form of laws in regulating flats through the Law of the Republic of Indonesia Number 20 Year 2011 on flat regulations called Undang-undang Rumah Susun (UURS). This law introduces a new ownership entitlement to property, that is, the property rights for the unit of flat (Hak Milik atas Satuan Rumah Susun/HMSRS), consisting regulations of individual rights over units of flats, collective rights to land, rights to objects and common parts which all constitute as an inseparable unity (Hutagalung, 2007).

Based on Indonesian flat law and regulation, flats are defined as multilevel buildings constructed in an environment which is divided into functionally structured sections, either horizontal or vertical. Flats are also deemed as units of residential which can be owned and used separately, especially for housing which are equipped with shared and common areas and land ${ }^{2}$. Thus, flats consist of units with the main purpose as residential, connected to public roads (Hutagalung, 2005).

Individual ownership of flat units has collective rights on common land, shared areas and objects. Common land means a right of plot of land or a leased land for a building used on an indivisible collective basis with the building permit. Shared areas is an indivisibly use of shared floors in functional units within the building. A shared object is an object that is not a part of a flat but a shared part indivisibly for shared use.

There are various activities in the management of flats which include development, control, utilization and management, maintenance, institutional and community roles that are implemented in systematic, integrated, sustainable, and in responsible ways. Thus, the development of flats should meet various technical and administrative requirements which are more strict than the construction of ordinary houses. The reason is that the flat is a multistory building and will be inhabited by many people, so there is a high requirement on security, safety and living satisfaction within the building (Hutagalung, 2005:197-198).

Recently, there are disputes at the court level in relation to flat management. The problem is, for instance, related to flat insurance where owners and tenants of the flats do not receive direct benefits from the building insurance. Legally, the association of owners and tenants of flats or called Perhimpunan Pemilik dan Penghuni Satuan Rumah Susun (P3SRS) is an organization which has a legal right to the arrangment of flats, not the flat management companies. Another instance of disputes is that developers or building contractors do not help or support in the establishment of P3SRS or in some cases developers or contractors tend to control flats management by establishing P3SRS through employees or tenants who can be 'managed' by developers or contractors. In some cases, developers or contactors continue to act directly or indirectly as flat management from the beginning of the flats development to the process of sale of entire flat units. Basically, P3SRS is the legal entity to act independently and becomes the representative of owners who is obliged to manage and protect the interests of owners and tenants related to common shared areas, land and occupancy (Sukarmadji, in Ramelan, 2015).

Furthermore, P3SRS as a legal entity is the only legitimate manager in the area of flats. Thus, this legal entity can not be replaced by other parties. However, the issue of management authority arises in relation to the term of "governing body" as stipulated in the Decree of the Minister of State for Public Housing as the Chairman of the National Housing and Settlement Policies and Controlling Agency Number 06/KPTS/BPK4N/1995/1995 on the Guidelines for Establishment of Articles of Incorporation, Articles of Association and by laws of the Housing Association of the Flat Residents, specifying an organization which has

\footnotetext{
${ }^{2}$ Indonesia law uses the term of "flats". However, there is another term used, namely "condominium". Condominium or condo is a form of residential where a particular part of real estate. Generally, apartments are privately owned where they can use of and access to facilities such as hallways, heating system, elevators connected with private ownership and controlled by the owners or association which describe the ownership of all parts. The term of flat is often used to refer to the unit itself replacing the words "the apartment." As the development of flats increased, there are number of apartments/condos for sale to consumers. Condominium is the legal term used in the United States and some parts of provinces in Canada. In the province of British Columbia in Canada, condominium is called a strata title. In Quebec, the term syndicate of co-ownership is used. In the United Kingdom (UK) and Wales, it is equal to commonhold, a form of ownership introduced in 2004, but it is uncommon in some places.
} 
responsibilities to carry out the task of managing the flats is "governing bodies". On the other hand, the provision of Article 75 paragraph (4) jo. Article 75 paragraph (1) of UURS mentions that P3SRS should be entitled to appoint a "manager" who is not a governing body. Thus, the word "body" seems to replace P3SRS legal entity.

Therefore, those problems related to the terminology of governing body are used as an opportunity for contractors or management building to commercialize shared areas of the flats by leasing out the collective rights such as communal properties, shared areas and land to third parties. Developers or contractors have actually sold the flat units, but in practice through the governing body, contractors then commercialize or lease those areas to third parties. As a result, the governing body generates income from several businesses such as parking area for residents, renting the roof of the building for Base Transmition Station (BTS) to telecomunication companies and restaurants or canteens to third parties without having accountability report to owners and tenants/residents. In other words, all income earned from those practices are not intended to provide benefits for owners of flat units and tenants and also there is no transparancy to owners of the flat units and tenants/residents as the standard rules has mandated in the UURS and the rules in the statutes/by laws or Anggaran Dasar - Anggaran Rumah Tangga (AD/ART ) of flats union.

Another issue related to residential/flat management is management fees, called luran Pengelolaan Apartemen (IPL) where flats management is an entity which is in charge in the collection process of fees. It is the fact that flat management acts as a collector of the fee. But, legally the right to do so according to the provisions of Article 75 paragraph (3) UURS is the association of residents and owners of flat units (P3SRS) (Sukarmadji, in Ramelan, 2015). The right to collect IPL fees, based on articles of association and by-laws of households and contractors, uses the letterhead of P3SRS. But, in reality, flat management companies often do not have permits such as domicile permits and permits to run the management of a building. Flat management companies often do not perform the obligation to hold annual general meeting of members in Annual Meeting/Rapat Tahunan (RUTA), at least two times a year, and it must be accountable. Information of the number of legitimate owners and occupants who attended the RUTA is often inaccurate and not transparent. It is controlled by managers to manipulate the number of votes in the ballots in each meeting to elect the P3SRS board or in assessing and ratifying the P3SRS financial report. This situation indicates that P3SRS ignores the obligation to report the number of tenants every six months to the government i.e Housing and Settlement Service Office. This means that letters from the government office in relation to ask data or information of the number of tenant is often ignored by management of P3SRS. Unfortunately, there is no concequences when they ignored the letters.

Moreover, flat management companies in collecting IPL do not based on real needs or real expenses as regulated in Article 57 paragraph (4) UURS. This collection results in losses of owners' and tenants' flats ${ }^{3}$. Flat management also collect water and electricity bills with value added tax (VAT). In fact, those bills are not subject for VAT. With reference to the provisions of Article 57 paragraph (4) of UURS, electricity bill should be based on real operational and maintenance costs. Electricity tariffs should be charged at the real cost, which is the amount paid to State Electric Company/Perusahaan Listrik Negara (PLN) divided by the amount of power used by tenants, without inflated (marked up). Flat management companies can not act as a power or an electrical company and/or an electricity seller which impose electricity tariff on tenants by adding up $10 \%$ operator service fee and $10 \%$ of value added tax (VAT) ${ }^{4}$.

\footnotetext{
${ }^{3}$ Regarding the provision of clean water, the property management company is not entirely supplier or seller of water, but secretly they have sold water waste water processing results with the level of quality of cleanliness appropriate laboratory test results TAPS Jaya only 0.8 (PDAM water standard PD PAM Jaya obliges $0.2=25 \%$ ) and the number of processed waste water being sold to citizens at a price of TAPS plus operator services $10 \%$ and VAT $10 \%$.

${ }^{4}$ There is indeed power consumption for shared needs, including for electrical generator set. However the costs are included in calculating the rate of service charge and bills to owners and tenants of flats. As the provisions of article 57 (2) paragraph UURS governing that proportionally in accordance with NPP respectively, property management is often argued that the price of electricity was raised because of the lost power. This act can be judged to violate the principle of fairness and makes no sense and violates the rules. Related to this, the fundamental issue is not about low or high price of the IPL, but it is how to determine
} 
In relation to collection fees by the governing body, the reserve or sinking fund is that the money belongs to owners and tenants which have been determined and it must be kept in separate accounts. However, from the beginning of operating flats the fund is saved in the accounts of developer companies or contractors, with no accountability to owners and tenants, as mandated by AD/ART. The flat governing body deliberately places the IPL funds which legally belong to the owners and tenants unlawfully, because the UURS requires the funds of those parties to be managed by P3SRS, as a non-profit institution and must be free from any business risk activity.

Based on various problems occured in the management of flats described above, it shows that central and local governments have not been able to prevent and overcome the problems. This paper, therefore, argues the importance of the government authority to prevent and cope problems, causing from flat management companies. Thus, this paper answers research questions: how do fraud and disputes occur in the management of flats; and how do central and local governments overcome fraud and disputes in an organization especially on the management of flats.

Case Studies on Fraud and Disputes in the Management of Flats: Case Law Approach. Fraud and disputes are two common cases between P3SRS and the flat management companies due to IPL arbitrarily. In this paper, the author discusses four different cases of fraud and disputes in the management of flats.

First is the case of flats in Jakarta, Indonesia where there was a termination of fraud and disputes through Central Jakarta District Court by Decision Number: 529/PDT.G / 2012/PN JKT PST. The actions of the governing body were not in accordance with the statutes and households of the mixed flats, and the increase of the IPL did not decide through a meeting and there was no socialisation of plan to increase monthly bills or management fees to tenants. As a result, one of tenants committed an act to report a property manager or flat management company to the police. This report has lasted for 4 years from 2008 to 2012.

Fraud and disputes on the flat management in relation to raising IPL without proper procedures, causing problems between governing body and P3SRS. However, the two parties did not respond at all, instead the governing body creates repressive and arbitrary actions by unilaterally shutting down the flow of electricity and water on the housing unit of the occupants. Moreover, the flat management company try to find faulty of tenants, which ended up with the criminalization of his conviction with the allegation that the residents of the flat units had illegally and without right exploited electrical facility in the corridor of the flats. The residents/tenants of flats claimed that their actions were to utilize the private rights of residents themselves on common objects and shared areas, as stipulated in the Statutes of Flats (AD/ART).

Utilization of facilities in the form of electricity which flows in corridors of the flats is indeed the right of each resident/tenant in accordance with the value of proportional comparison that represents the absolute right of each occupant to common areas and objects. Consequently, if the governing body considers the act of utilizing the common facilities to be considered an act categorized as violating the ART, it should be resolved through a bipartite dialogue between tenants and the P3SRS. If bipartite dialogue does not come up with good decisions or results, then the problem is brought into a tripartite dialogue, involving supervisory institutions owned by the government, called Dinas Perumahan and Kawasan. Unfortunately, the procedure of this dialogue has not been regulated by law, so that all 'small' problems are brought to justice institution either civil or criminal by making a complaint to the police. However, in practice, contractors/developers who are often called management building with the power of P3SRS claims to be a manager with the same authority with the P3SRS authority. Whereas management building does not have the capacity to act on behalf of the tenants and owners of flats. The position of management building is to perform P3SRS obligations. 
The second case of fraud and disputes in the flats management is between the P3SRS of a mixed flat against the residents/tenants of flats. This case has been decided by the Central Jakarta District Court Decision Number 510/Pdt.G/2013/ PN.Jkt. Pst. In this case, the P3SRS acts as an arm of a building management that claims to be the management agency, collecting money from flat owners who are unwittingly aware of the occupants, even raises the IPL significantly without the approval of the flat owners. The actions of the governing body violate the rules of law and rules in the AD/ART. The money collected is never accounted transparently as required in the AD/ART. Various methods are used by P3SRS to take sides and to protect the economic interests of the management building. However, by placing the people from the governing body to become P3SRS board and one of the requirements to become P3SRS should be prioritized to owners or residents/tenants who live in the flats.

P3SRS as a governing body is entitled to issue a threat warning against the flat owners, but in reality management building conducts execution action against the owners, such as the cutting of electricity and water with the intention that the residents/tenants of the flats pay all the bills where this act is actually illegal. In many cases, the governing body, further, intimidates tenants by using hundreds of security unit officers when there are protest from flat owners at the time of organizing RUTA ${ }^{5}$, especially at a meeting in changing P3SRS boards.

Residents of the flats are also disappointed when the governing body does not report IPL collection fund without transparency, requiring the governing body and P3SRS to, in good faith, submitting copies of bookkeeping records and financial management reports. These demands are actually reasonable because the financial statements are the right of residents/tenants.

The third case of fraud and disputes is between the organization of the merchant association and the owner of flats (rival) with P3SRS residential and non-residential homes and a trading center. This case has been decided by the Supreme Court with Supreme Court Decision Number: $236 \mathrm{~K} / \mathrm{TUN} / 2016$. In this case, the flat governing body conducts the General Meeting of P3SRS Elections witnessed by the Governor of the Special Capital Province of Jakarta Province. However, the General Meeting was conducted without involving the traders and residents/tenants of the flat. The general meeting was attended by a majority of development staff and the majority of non-owners and residents of mixed commercial houses and trade centers, among others: the owners and residents of the flat units and trading centers, developer employees and governing body.

The Governor of the Special Capital Region (DKI) of Jakarta through the Head of the Housing and Building Agency of the Provincial Government of DKI Jakarta subsequently plans to issue the Decree of the Governor of the Special Capital Region of Jakarta Number 273 of 2014 in connection with the ratification of the Deed of Owner Association and the Residents of the Mixed Commercial Flats and Trade Center. However, against the Decree of the Governor of Jakarta Capital Special Region (DKI), the residents/tenants through the forum of the association organization of the flats' owners submit a letter of objection and continue to attempt to send a letter to all parties in order not to publish and legalize the P3SRS Formation Act. This effort lasted more than three years from February 2011 to February 2014 but finally the Governor of Jakarta still issued the Decree. The residents/tenants of the flats considered that the Decree of the Governor of Jakarta was very harmful to them. Thus, based on this reason, the residents/ tenants filled a lawsuit to the Jakarta Administrative Court.

The fourth case of fraud and disputes is between the owners of the flats which is also a company in the form of P3SRS flats and the Provincial Government of the Special Capital Region (DKI) of Jakarta which issued a Decree Number: 1329 related to the legalization of the deed of establishment of Flats' P3SRS. This case has been terminated by the Jakarta Administrative Court Number: 218/G/2011/ PTUN-JKT. The Company as the owner of 37

\footnotetext{
${ }^{5}$ The obligation to hold a RUTA that is set up by default in the by law should be held minimum once a year to ask for consent and legalize the use of operational costs of the previous year. RUTA is usually held only at the time of the expiry of the management of P3SRS and simultaneously turn the administrators P3SRS.
} 
(thirty seven) units of flat units filled a lawsuit against the Provincial Government of the Special Capital Region of Jakarta for issuing decision letter, number: 1329, related to the legalization of the deed of establishment of P3SRS. The company as the owner of 37 units of flats felt that the Decree of the Provincial Governor of the Special Capital Province (DKI) of Jakarta had harmed the company because it had been based on false legal considerations and it was not supported by legal facts which occurred and contrary to the laws and regulations.

The Decree of the Provincial Governor of the Special Capital Province (DKI) of Jakarta decides: (i) ratification of the goodness of Establishment of the Housing Association of the Flats; (ii) a copy of this Governor's Decision should be granted to subsequent applicants to P3SRS members; (iii) decision of the Provincial Governor of the Special Capital Province (DKI) of Jakarta should be effective on the date of stipulation. The Company as the owner of 37 units of flats assumes that the implementation of the meeting of the establishment of P3SRS does not comply with the positive law and the propriety principle. As long as the association has not been formed, the interests of the management with the owners and tenants done by the company as the developer become the temporary administrator of P3SRS in accordance with the provisions of Government Regulation Number 4 Year 1988 regarding flats/government regulations.

The company as the owner of 37 units of flats as the temporary P3SRS management sent a letter of invitation to the establishment of P3SRS to elect, establish and authorize the P3SRS board and authorize AD/ART of the dwelling house association. However, the meeting was not attended by all owners and residents of the flats because they did not accept the invitation. The meeting was attended only by a small portion of the owners and residents/tenants of flats. The company as the owner of 37 flat units was suspected that they just invited only the flat owners whereas the government regulation of flats has made it clear that the members of the flats association are legal subjects owning, using, renting, utilizing the respective flat units. However, the formation meeting did not discuss and validate the meeting as the basis or foundation in the implementation process of the formation meeting. Whereas, the order of meetings becomes the basis of decision. According to the principles of democracy and propriety, it is required to organize a meeting aimed in arranging the meeting to establishment P3SRS. Thus, the formation meeting can be judged as procedural defect.

Exercising Government's Authority to Overcome Fraud and Disputes in the Flats Management. To understand the government's authority in resolving disputes in the flat management fees has recently become a trend in developing countries. There is the fact that a theoretical description as well as in practice of two distinguishable terms: government and governance. Governance relates all affairs undertaken by the state in carrying out the welfare of society and the interests of the state. Government is an entity to implementation government duties or an organ/tool or apparatus (Ridwan, 2006).

Government means the completion of the state which can be interpreted broadly or narrowly. In a broad sense, the government includes all the fittings of the state, essentially composed of executive, legislative and judicial power or other state apparatus, acting for and on behalf of the state. Whereas, in a narrow sense, the government is the branch of the executive power. In a narrow sense, the government is a tool of state organ entrusted with the task of government to perform the law. Whereas in a broad sense, the government includes all bodies that organizes all power within the state: executive, legislative and judicative. In the literature, government can be understood in two terms: as a function and as an organization (Ridwan, 2006).

Political power is the power to influence policy with its formation and consequences in accordance with the purpose of the holder of power itself. Political power is a part of social power, focusing on the state as the only authoritative party with the right to control social behavior by force. Political power not only includes the power to gain the adherence of the citizens, but also to the control of others with the aim to influence acts in the administrative field. Political power requires the use of power (machtsuitoefening). Power must be executed effectively in order to take control. To use political power requires the rulers, i.e the perpetrators who hold power with tools/means of power (machtsmiddlen) for the use of 
power that can be done well. As a result, government exercises power (Budiardjo, 2011). Thus, governance can be understood in two senses: government function or commanding activity and governmental organization as the collection of governmental units (Hadjon, 1999:6).

The ruler or the government needs authority. In this regards, according to Budiarjo (2011), authority is related to power. Power is the ability of a person or a group of human beings to influence the behavior of a person or other group in such a way that the behavior becomes in accordance with the wishes and purposes of the person who has that power. Human beings have a variety of desires to achieve. To be able to make it happen, often they impose their will to other people or groups (Budiardjo, 2011).

The governmental authority is related to government administration. Activities in government administration under Article 4 of Law Number 30 Year 2014 on Government Administration encompass all activities: performing government functions within the scope of the executive, judicial, legislative; and to carry out the functions of government mentioned in the 1945 Constitution of the State of the Republic of Indonesia and/or the law. Thus, government administration arrangements include several aspects i.e. the rights and obligations of government officials, governmental authorities, discretion, administration of government, administrative procedures, government decisions, administrative efforts, fostering and development of government administration, and administrative sanctions.

In the implementation of its authority, the government as an agency or state sdministration sfficer may make a written stipulation, that is, the determination made by the state administration or administrative officer in the form of a concrete, individual and final state law action, which has a legal effect on a person or legal entity civil. The consequences of the law in the form of losses arising suffered by people affected by the decision. In relation to the written stipulation, Indroharto is more concerned with the content and not the format issued by the state administration or administrative officer. Written requirements are required for ease of evidence. Therefore, a memo or memorandum may meet the written requirements and will constitute a decision of the Board or Administrative Officer of the State under the PTUN Law (Siahaan, 2005).

Elements of state administrative law actions are distinguished from the actions of the government which is a legal action and the actions of the government which is a factual action. The authority of state administrators is only the actions of the government which is legal action, not the factual action (Siahaan, 2005:181). The authority of the State Administration Officer in making a written decree may result in legal consequences of the loss incurred, suffered by a person who is affected by the decision.

In relation to the actions of the government including act of laws, Indroharto says that the legal actions include; a decision intended to commit material deeds or goodness; refusal to repeat written appointments which have been issued; provision of written information; written preparatory acts as preceding the issuance of the actual written decisions; decisions that have not been defined as definitive and binding decisions; decisions which intended to bring about a legal effect but they are actually impossible to cause any legal effect; decisions that simply refer to existing legal; and decisions which relate to orders (Siahaan, 2005:81182).

Concerning to the government affairs, the Elucidation of Article 1 Sub-Article 1 of Law Number 5 Year 1986 regarding State Administrative Court as recently amended by Law Number 51 Year 2009 on the Second Amendment to Law Number 5 Year 1986 regarding State Administrative Court, states that government affairs are executive activities. Basically, the government does not only implement laws but also follows the principle of freies ermessen which can perform other acts even though they are not yet explicitly regulated by law. Dutch literature is more popular to use the term of bestuur rather than the term of uitvoerende macht. In relation to state administrative decisions, besides executive decision or gehonden beschikking, there is also a discretionary decision or vrij beschikking. Dutch literature describes the bestuuren or field activity as the entire field of state after deducted by regelgeving and rechtspraak. Thus, if the definition of state administration is defined as 
government affairs, it does not only include executive activities only. Perhaps, the Dutch concept can be used to formulate a proper understanding of government affairs.

Utrecht distinguishes state administrative decisions in several classifications: 1) the provisions of positive and negative decisions; 2) declaration of constitutions and constitutive provisions, quickness and fixed determination (bijvend), and 3) dispensation and permit (vergunning). Positive provisions cause rights and obligations to those determinated subjects. Negative provisions do not result in changes of existing legal circumstances. Thus, negative provisions can be in the form of a statement of inaction (onbevoegd verklaring), a statement for either acceptance or not acceptance (niet-onvankelijk verklaring) or an objection (afwijzing); declaration and constitutive provisions. The declaration decree only states that the law is formed (rechtvastellende beshikking) and constitutive provision is to make the law (rechtscheppend) (Hadjon, 1996:142).

The flat management needs the government's role in the context of arrangement and assistance on flats which aims to improve the housing construction and functional housing for people's benefits. Arrangement and supervision of flats can be conducted on the basis of public policy, technical policy, and operational policies set up by each authorized agency. Thus, arranging and assisting flats are intended to support spatial conceptions, associated with urban development towards the vertical and also to rejuvenate slum areas. The government's role is also to improve optimization of the use of urban land resource and to support the development of high-density settlements.

Managing and assisting flats should include provisions on the technical and administrative requirements for the construction of flats. The technical requirements means the structure of building, health and safety, convenience related to design, and the completeness of infrastructure and environmental facilities which are regulated by legislation and adapted to the needs and developments. Administrative requirements, on the other hand, are the requirements concerning on business license of a housing construction company, permit or allotment of building/ljin Mendirikan Bangunan (IMB), as well as the readiness of place which is the subject to legislation and tailored to the needs and developments.

Other provisions made for regulating and assisting flat projects include several aspects such as living permits, ownership of flat units or residential, and management and supervisory procedures. General arrangements and guidance in the widest sense of the development of flats should be under the authority and the responsibility of the central government conducted by a Minister as appointed in the relevant article in government regulation. Thus, the role of government should prevent and minimize potential conflict among flats management, owners and tenants. Therefore, the role of the government is required. In this regard, the government is deemed necessary to supervise the implementation of duties and responsibilities of the management of P3SRS and flat management companies.

The Importance of Administrative Sanctions. Governance is run and operated with govermental instruments. In this regard, Ridwan (2006) argues that government's instruments are tools used by government or state administration in performing their duties. Thus, the government or state administration should use juridical instruments in carrying out activities of the government as well as governmental and civic affairs, such as laws and regulations, decisions, policy regulations, licensing and civic law instruments (Ridwan, 2006:129).

In exercising authorities, the government as an official state administration may impose administrative sanctions. According to Hadjon et al (1999), administrative sanctions include: government coercion (bestuursdwang); the withdrawal of decisions on permits, payments and subsidies; imposition of administrative penalties; and the use of forced money by the government (dwangsom). In addition, Bestuur are concrete actions (feitelijk handeling) of rulers to end a prohibitted actions under administrative law or on going actions which have to be abandoned by citizens since the actions are against the law. Thus, Bestuurdwang is the act of the ruler in a very direct way. Other sanctions play indirect (weken meer indirect) through imposition of administrative fines. 
Implementation of sanctions by state administration should always be held on the basis of strict legislation. For the imposition of administrative fines must be absolute and unconditional obligations under a strict rule of law. In the past, state administration was supposedly in charge of taking necessary actions adjusting the real situation to what the law was established. If the citizen ignores the law, the authority of bestuurdwang has a consequence of the government's duty where the state administrative body has been given tasks in implementing legislations.

While, in the Netherlands, the authority of bestuurdwang is governed by law. However, the authority of bestuurdwang is always regulated in various laws. It can be determined that bestuurdwang can only be applied whenever there is an authority through legislation. Currently, a state administrative body confirms that it has the authority to run bestuurdwang when the authority is not based on the law. Government sanctions apply a decision that provides burden (belastende beschikking) (Hadjon, 1996:246) which represents the nature sanctions (Hadjon, 1996:247). But, the government can only impose sanctions in the case of violation of laws and regulations. In practice, government or state administration chooses employees who are assigned to conduct supervision. Such supervision is a requirement for the possibility on imposing sanctions. In other words, supervision can also support law enforcement (handhaving). In more preventive ways, employees can also conduct counseling to citizens, as well as advice, and a form of warnings in order to prevent the occurrence of sanctions (Hadjon, 1996:248,258) ${ }^{6}$.

The state is responsible for the regulation of flat management which is stated in the UURS. To fulfill these responsibilities, the government is obliged to carry out guidance on a tiered basis by Ministers at the national level, Governors at the provincial level and Regents/Mayors at the district/city level. Responsibility for the construction of flats can be done by synchronizing and socializing the legislation, policies and strategies for the flats management at the national level. The synchronization needs to be done is the Law which regulates the flats and this is supported by government regulations. Regulations at the relevant ministerial level also need to be enacted more fully and synchronized with the UURS. All legislation products should also be disseminated to provincial government, districts/cities, communities and all stakeholders.

In relation to stakeholders, the government can also empower them to develop and set minimum service standards of flats and to coordinate and facilitate the preparation and provision of database of flats at the national level. To carry out its responsibilities and duties, the government may exercise its authority, including establishing legislation, norms, standards, procedures, and criteria in the field of flats, facilitating the management of common areas and objects together with ordinary, private and state flats. The government may also use its authority to coordinate the supervision of the implementation of legislation regarding flats arrangement. Such supervision is also intended to provide legal protection to every stakeholder of the flats. Legal safeguards are undertaken by the government against each stakeholder for the flats legislation (Handajani, 2015). Legal protection is carried out both preventive and repressive. Preventive legal protection is made by involving all stakeholders. This presents opinions and objections to definitive government policies. While preventive law protection aims to prevent the occurrence of problems and disputes on flats issues, while repressive legal protection aims to resolve disputes (Handajani, 2015:44).

Not only at the central level, the government has the responsibility to undertake deep coaching at the provincial level. In relation to this responsibility, the provincial government has tasks to formulate policies and strategies on flats issues at the provincial level by referring to national policies and strategies, implementing synchronization and socializing legislation of policies and strategies for flats management at the provincial level. The provincial government has also a duty to carry out the operational function of the policy by providing flats and developing flats as part of the settlement area and empowering stakeholders at the provincial level.

\footnotetext{
${ }^{6}$ In the Netherlands, legislation always requires an acceptance which is in urgent circumstances; a written warning must precede the implementation of bestuurdwan. This provision is a set forth in article 152 paragraph (2) Gemeentewet.
} 
To undertake assistance, the provincial government may use its authority to develop guidance on the implementation of norms, standards, and procedures in the flats management set by the government. The provincial government can monitor and evaluate the implementation of the policy and strategy of flats at the provincial level as well as supervise and control the implementation of legislation, policies, strategies and programs of flats at the provincial level. The provincial government may also facilitate the management of common areas and objects with ordinary, private and state flats at the provincial level.

Supervision by the government can prevent the occurrence of fraud in collecting monthly management fees. The government needs to be firmed if it finds the parties who collect IPL besides P3SRS. Supervision also needs to be done to flat managers who often do IPL collection which is not based on real needs, resulting in losses for owners and residents/tenants of flats. In terms of water and electricity bills, they in practice are often to be subject to Value Added Tax (VAT), which legally should not be allowed to be charged since water and electricity bills are classified as basic needs so they are not the subject of VAT.

Government needs to pay attention to fraud on flat management where the case of collecting IPL fees must be agreed by owners and tenants. Supervision on IPL collection is important since in practice flats management often do not have permits, such as domicile permits and permits to run the management of a building. Flats management often do not perform their obligations to hold RUTA twice a year which they have to hold accountability. Supervision by the government in organizing flats includes several aspects: planning, controlling and supervising. In terms of regulation, the government may make provisions in governing, developing, controling, and utilizing flats. The issues also includes management and institution, quality improvement, and funding or financing systems.

In terms of control system, the government is expected to guarantee the flat management working in accordance with its objectives. Control can be done at the early stage when developers start planning to develop buildings. Control system should continue to the stage of development, ownership, utilization and building management. The management of flats at the planning stage is done through assessment of the suitability of the number and types, zoning suitability, location compatibility and certainty of availability for public utilities. The management of the flats at the stage of development is carried out through evidence of land ownership and conformity between building development and permit. The management of flats in the stage of ownership is done through the certification of flats' function, proof of land and building ownership and the ownership of flat units. Management stage should be conducted through supervision on the establishment of P3SRS, supervision of the management of common areas, objects and land. The flat management is carried out by the government through licensing, inspecting and controlling.

\begin{tabular}{|c|c|c|}
\hline $\begin{array}{l}\text { Functioning and } \\
\text { Strengthening Government } \\
\text { Authority } \\
\text { Setting up a monitoring system } \\
\text { and administrative procedure } \\
\text { and sanction on the flats } \\
\text { management. } \\
\text { Monitoring flat management } \\
\text { companies for complying with }\end{array}$ & $\begin{array}{l}\text { Flats Management } \\
\quad \text { Companies } \\
\text { Implementing all flat } \\
\text { legislation and } \\
\text { administrative } \\
\text { procedure, monitored } \\
\text { by the government. }\end{array}$ & $\begin{array}{c}\text { Owners and Tenants } \\
\text { of Flats } \\
\text { Practising rights and } \\
\text { obligations as owners } \\
\text { and tenants under } \\
\text { UURS, AD/ART and } \\
\text { the agreement with } \\
\text { flats management } \\
\text { companies. }\end{array}$ \\
\hline
\end{tabular}

Figure 1 - Framework on Strengthening Government Authority to Overcome Fraud and Disputes in the Flats Management

Control system on flats is in relation to the government's power which is in the political field, affecting the general policy of its formation and its consequences in accordance with the objectives of the government function. This power is to control the actions of all 
stakeholders to be obedient to the flats legislation and to influence their actions to comply with administrative procedure (Zayim, 2014). Control system is exercised by the government in the sense of making administrative decisions including imposing administrative sanctions to all stakeholders of the flats.

In exercising the government's authority, it is necessary to make administrative decisions in the form of written stipulation to all issues which may be considered as disappointing and unfair. Thus, the government's authority could help all parties who feel disadvantaged to file a lawsuit to the state administrative court. The lawsuit usually intersects with the government's decision whether a state administrative official revokes, declares null or avoid. According to Ridwan (2006), exercising the authority and maintaining the norms of administrative law and government organs can act as defendants in the judicial process, namely, in the case of any objection, appeal or resistance (Ridwan, 2006:77).

In making administrative decision, local governments also have authority under the provisions of Article 71 paragraph (1) UURS, which can control the implementation of flats, using several instruments. They are licensing, inspecting and controlling. However, such authorities have been limitedly restricted under the provisions of Article 71 paragraph (2) of the UURS where the implementation of controls should be governed by a Government Regulation (Peraturan Pemerintah). Nevertheless, local leaders such as Governors, Regents and Mayors have authorities to issue a Governor or Regional Regulation. It is, therefore, expected that legal certainty and protection of ownership and right to obtain proper and harmonious living as required by law can be achieved through Government protection.

\section{CONCLUSION}

In the management of flats, problems of fraud and disputes occur as an impact of management fees or monthly building maintence (IPL). This paper has discussed several case studies in the area of DKI Jakarta, Indonesia where fraud and disputes appeared in the court. Common problem raised when there is a difference assumption and understanding on the practice of collected fees and bills for the owners and tenants by flats management companies or building management. This paper argues that ideally there should be an approval of owners as well as tenants of flats in the flat management fees and monthly bills. From case studies, this study found that collected fund has never been accounted transparently by the governing body or the flats management companies as stipulated in AD/ART. In other words, there is no consent form in the collection process as well as transparency on financial reporting of collected fees and bills. In addition, this research also found that the merchant associations, tenants and owners of flats are disappointed with the P3SRS as the governing body which was formed by flats management companies. In order to prevent and mitigate fraud and disputes in the management of flats, the central and local governments could use their respective authorities in the administration of flats under their jurisdiction through controlling actions of all flats' stakeholders in order to comply with the flat legislation. Thus, this paper offers a framework to significant departures in the flat management issues. Further strategy under the government authorities is that the government could enact the administrative procedures in the form of written stipulation.

\section{REFERENCES}

1. Aalbers, B. M., and Gibb, K. (2014). Housing and the Right to the City: Introduction to the Special Issue. International Journal of Housing Policy. Volume 14: 3.

2. Budiardjo, Miriam. (2011). Dasar-Dasar IImu Politik (edisi revisi)/ Fundamentals of Political Science (revised edition), Gramedia Pustaka Utama, Jakarta.

3. Decree of the Minister of State for Public Housing as Chairman of National Housing and Settlement Development Policy and Control Agency Number 06/KPTS/BPK4N/1995 Year 1995 on Guidelines for Establishment of Deed of Establishment, Articles of Association and By-Laws of Flat Residents.

4. Decision of Supreme Court Cassation Number: 236 K / TUN / 2016. 
5. Decision of Central Jakarta District Court Number: 529 / PDT.G / 2012 / PN JKT PST.

6. Decision of Central Jakarta District Court Number 510 / Pdt.G / 2013/ PN.Jkt.Pst.

7. Douglas, G., Pearce, J., Woodward, H. (2007). A Failure of Trust: Resolving Property Disputes on Cohabitation Breakdown. Cardiff Law School Reseacrh Papers: 1.

8. Hadjon, Philipus M. (1999). Pengantar Hukum Administrasi Indonesia/ Introduction to Indonesian Administrative Law. Gadjah Mada University Press, Yogyakarta.

9. Handajani, S. (2015). Perlindungan Hukum bagi Konsumen Satuan Rumah Susun. Aswaja Pressindo, Yogyakarta.

10. Hutagalung, Arie S. (2005). Tebaran Pemikiran Seputar Masalah Hukum Tanah. Indonesian Legal Empowerment Institute. Jakarta.

11. Hutagalung, Arie S. (2007). Kondominium dan Permasalahannya, Edisi Revisi. Legal Body of the Faculty of Law University of Indonesia. Jakarta.

12. Indonesia's Government Regulation No. 4 of 1988 on Flats.

13. Law of the Republic of Indonesia Number 20 Year 2011 on Flats.

14. Law Number 30 Year 2014 on Government Administration.

15. Law Number 5 Year 1986 regarding State Administrative Court.

16. Law Number 51 Year 2009 on the Second Amendment to Law Number 5 Year 1986 regarding State Administrative Court.

17. Leks, Eddy Marek, (Chairman of the Working Group). (2013). Analisis dan Evaluasi Peraturan Perundang-undangan tentang Perumahan Rakyat. National Legal Development Planning Center National Legal Development Board of the Ministry of Justice and Human Rights.

18. Letter of the Director General of Taxation Number: S-139/PJ/2013 dated May 24, 2013

19. Public Communication Center Ministry of Public Works and People's Housing of the Republic of Indonesia. (2018). Baclog Perumahan Mencapai 5.8 Juta Unit, at https://www.pu.go.id/berita/view, accessed January 28, 2018.

20. Ramelan, E. (2015). Problematic Legal Property of Flats for Housing and Transition of Land Rights. Yogyakarta: Aswaja Pressindo.

21. Ridwan, HR. (2006). Hukum Adminstrasi Negara. Raja Grafindo Persada, Jakarta.

22. Siahaan, Lintong O. (2005). Prospek PTUN sebagai Pranata Penyelesaian Sengketa Adminstrasi di Indonesia Studi tentang Keberadaan PTUN Selama Satu Dasawarsa 1991-2001. Perum Percetakan Negara RI.

23. Sutedi, Adrian. (2010). Hukum Rumah Susun \& Apartemen. Graphic Sinat, Jakarta.

24. United Nations Human Settlements Programme (UN-HABITAT). (2018). The Role of Government in the Housing Market: The Experiences from Asia. First published in Nairobi.

25. Zayim, A. (2014). Differentiated Urban Citizenship and Housing Rights: Analysing the Social Impacts of Urban Redevelopment in Globalizing Istanbul. International Planning Studies, Volume 19: 3-4. 